\title{
Research on Teaching Reforms of the Three Constitutions Course of
}

\section{Environmental Art Design}

\author{
Zhifeng Zhang ${ }^{1}$ \\ ${ }^{1}$ Planning and Design College of Xinyang Agricultural and Forestry University, Xinyang City, \\ Henan Province, 464000
}

Keywords: Three constitutions, Environment Art Design, Teaching reforms

\begin{abstract}
The three constitutions course is fundamental in the art design curriculum, which bears the important task of enlightening design thinking of students. However, the teaching model in the basic three constitutions course is stereotyped in China's higher education currently. The solidified thinking model with no differences and no emphasis among majors affects students' innovation in their profession learning. This paper analyzes problems and proposes reform strategies in the three constitutions teaching, which is based on the author's teaching experience for many years. The author hopes to lay a solid foundation for students who specialize in Environment Art Design and want to learn it better.
\end{abstract}

\section{Introduction}

The three constitutions is a general term for plane composition, color composition and three-dimensional composition, which has been an important part of modern art design education system. Plane composition is to combine different basic shapes together into a new pattern according to some rules in a two-dimensional space; color composition is to construct mutual relationship between elements to create a new and ideal color effect in accordance with a certain color principles; the three-dimensional composition is to use various materials to create a beautiful 3D model in accordance with mechanics and certain principles of constitution.

The teaching model in the basic three constitutions course is stereotyped in China's higher education currently. The solidified thinking model with no differences and no emphasis among majors affects students' innovation in their professions. Therefore, the author assumes that the three constitutions course teaching should take reforms and innovation based on professional characteristics. Furthermore, we should connect major teaching with the model, content and methods of the three constitutions course teaching, in order to enable students to combine the three constitutions with their major in the process of learning their profession. This will promote the effectiveness of the three constitutions course which is the basic class of major of Art Design. The writer will discuss some thoughts on the three constitutions course teaching in major of Art Design.

\section{Problems Analysis in the Three Constitutions Course Teaching}

Curriculum provision is similar among majors. Presently, a majority of art academies and comprehensive universities have set up major of Art and Design, which is consistent with the development of contemporary society. Art Design includes a number of professional emphases: visual communication design, industrial design, landscape design, animation design, garden design and others in addition to environmental art design. Their curriculum all contains three constitutions course and the curriculum provision of this course is fundamentally similar. Not only the number of hours, forms, methods and teachers of teaching is same, but also the teaching content. They even do 
not differ in content and forms based on different professional emphases. People cannot tell the differences between professional emphases when see school assignments in the exhibition. The above situation cuts off the link between curriculum and majors, which leads to a students' mistake that there is no direct relation between curriculum and majors and less attention to all courses.

The teaching model is single. There is not much change and development of the three constitutions for a long time after it was introduced into our country. Although there are many published materials, the content basically repeats the early textbooks with some changes on the reference images and chapters arrangement. The teaching model is also a continuation of traditional teaching methods: to teach theoretical knowledge on materials in the multimedia classroom and to organize students to do hand-painted practice. The form of assignment is single and many students just imitate case copy in painted books. For example, the homework of plane composition is usually to use points, lines and planes to form a pattern in a predetermined square; the assignment of color composition is to complete the training of hue, lightness, and saturation by painting color blocks; the work of three-dimensional composition is like a handmade lesson with simple materials and unclear form. The neat and evenness of painting are always the scoring criteria which exaggerate the effect of this course and ignore the creative process. The overly stereotyped teaching model makes students just gain the fundamental knowledge in the books and confine their thinking. They are unable to understand the composition and the relationship between the three constitutions and their majors, so that it is difficult for them to utilize knowledge flexibly in the future.

There is a lack of pertinence in the teaching objectives and content. The three constitutions course itself has a specific teaching goal, which aims to develop students' feelings about the shape, to exercise the ability of form portray and to improve their own aesthetic quality. The teaching content based on this objective is generally universal. For example, the plane composition focuses on the abstract combination of points, lines and planes and basic concepts of shape; the color composition pays attention to the basic properties of colors, balance of colors and comparative techniques; the three-dimensional composition aims to develop students' ability of three-dimensional objects and the expression of the materials and textures. Such universal teaching content plays a very important role in students' ability of shaping, but the three constitutions do not limit to this from the standpoint of Environmental Art Design. The lack of targeted educational content cannot allow students to appreciate the relationship between the three constitutions and art design in a short time. On one hand this will affect the enthusiasm of the students to learn constitution knowledge, and on the other hand, it will lead to unclear concepts of constitution in students' mind after the end of the course. Therefore, it is difficult for them to apply constitution knowledge to environmental art creation.

\section{Reforms of Teaching Model of the Three Constitutions Course}

Set characteristic curriculum. Although the course has the same name, it is different with specific students and professional emphases. The curriculum of the three compositions in Environmental Art Design should differ from other majors according to its own professional features. They should connect the choice of instructors, the organization of teaching forms, the arrangements of course time and the selection of materials with professional features. First of all, instructors may well have educational background of Environmental Art Design. Although they grant the same basic knowledge, different teachers have different directions at guiding students to diverging thoughts and teachers in Environmental Art Design will tend instinctively to design-related content in the analysis of cases. For example, taking architectural form constitution or garden layout as an example to illustrate the constitution knowledge can integrate theories into professional design and 
deepen students' understanding of the constitution knowledge. Secondly, the course time is not necessarily consistent with other majors based on the professional features and should be arranged after students already have had some design knowledge and mastered the engineering drawing skills. Therefore, it can act as a transitional link between design learning phase and early design training stage. Such arrangement enables students to show their assignment in a simple work of environmental art design with proficient drawing skills. Finally, the materials also should be related to design or construction of environmental art, which focus on the analysis of specific cases of environment art design or architectural design, and guide students to analyze and understand works of environmental art design from the perspective of constitution.

Establish diversified teaching models. In the curriculum of Environmental Art Design, the three constitutions course is fundamental in interior design, garden design, architectural design, landscape design and others, which will lay a solid foundation for further professional study. Therefore, teachers should adopt diversified teaching models in teaching, and integrate knowledge of constitution and knowledge of design together. On one hand, instructors should teach basic theoretical knowledge in textbooks. On the other hand, teachers ought to make full use of network resources and put the image and video data into chapters and sectors in order to make breakthroughs and expand students' knowledge. Furthermore, they can take students to have a field study of school buildings or campus landscapes to make an analysis of constitution knowledge of these projects, which will stimulate students' interest in learning. In terms of the assignment, instructors should break the traditional practice model and make students complete their works with simple environmental design project. For example, in the homework form of plane composition, students may use points, lines and planes to fulfill the design practice of background walls whose sizes have been limited .In terms of color composition, students can take living space as an example and set several scenes, such as the girls' bedroom, newlyweds' bedroom, middle-aged teacher studies and so on. They can complete the color configuration on a square. For the three-dimensional composition, teachers can take different topics as the theme and conduct landscape constitution practice. It is also selective to make students complete the plane, façade and profile map of constitution work based on the requirements of the project case. The scoring criteria should not only base on accomplishment and carefulness of their homework, but also on students' originality. This will lay a solid foundation for professional project practice.

Set targeted teaching objectives and content. Different from other art design majors, the constitution course and teaching objective of Environment Art Design is to enable students to recognize the close relationship between constitutions and environment art design and master the importance of the constitution knowledge associated with environment art design. Moreover, this will enable them to grasp certain shaping and lay a solid foundation for the further study of professional design. In the teaching content, teachers should set up some targeted constitution courses that are based on professional features of environmental art design and the characteristics of interior design, landscape design and landscape design. In the plane composition, courses ought to put the form constitutions and group relations into space starting from constitution relations of points, lines and planes, such as the wall and ground decoration constitution in interior design, the vegetation constitution in garden design and so on. In this way, once students engage in plane constitution, they will be able to find a meeting point between the curriculum and the major. The color composition has a direct relation with environment art design, which plays a role in changing and creating styles in interior design. Therefore, instructors should change the traditional teaching methods and ideas and introduce into color composition and architectural color design into the interior space so that students can have a deeper thinking on the learning professional knowledge. 
The course of the three-dimensional constitution should add space constitution which is closely related to environment art design. The organization and division of space is very important in interior design and architectural design, which is a basic skill for students. Therefore, in the course of the three-dimensional composition, it is critical to strengthen the training of the space composition for students to make students realize the relationship between constitutions and environment art design clearly.

\section{Conclusion}

The three constitutions course is an important part in the teaching of Environmental Art Design, but there still exist some defects in the constitution curriculum of Environment Art Design. As an environment art design teacher, the author tries to find the meeting point between the three constitutions and Environmental Art Design, to make the constitution course, which is the basic professional course in Environmental Art Design, play a more supportive role in this major, to form a new and intact teaching theoretical system of new thoughts, and to make my own contribution to the construction of professional disciplines.

\section{References}

[1] Zhang Rongquan, Wu Haiyan, Xia Jianhong Jiang Xing, Zhang Chao. The Discussion about the Teaching Reform of Environmental Art Design in Higher Colleges ----A Case Study of Minxi Vocational and Technical College [J]. Jiannan Literature (Classical Teaching), 2012,10: 394-395 + 397.

[2] Wang Yongqiang. A Discussion on the Teaching Reform of Environmental Art Design [J], Era Trade, 2007,11: 193-194.

[3] Ma Jun. The Teaching Reform of Environmental Art Design in the Information Age [J], Journal of Shaoguan University, 2011,01: 150-152.

[4] Yan Hongying, Li Wen. The Teaching Reform and Innovation of the Three Constitutions Course in Environmental Art Design [J], Journal of Yancheng Teachers College (Humanities and Social Sciences), 2013,05: 99-101

[5] Zhong Yan. The Teaching and Development of Environment Art Design in Guilin Colleges [D],Guangxi Normal University, 2009. 